\title{
Protein Adsorption on Hybrids of Thermoresponsive Polymers and Single-Walled Carbon Nanotubes
}

\author{
Kazuo Umemura, ${ }^{1}$ Katsuki Izumi, ${ }^{2}$ Yoshikazu Kumashiro, ${ }^{3}$ \\ Shusuke Oura, ${ }^{1}$ and Teruo Okano ${ }^{3}$ \\ ${ }^{1}$ Department of Physics, Graduate School of Science, Tokyo University of Science, 1-3 Kagurazaka, Shinjuku, Tokyo 1628601, Japan \\ ${ }^{2}$ Graduate School of Mathematics and Science Education, Tokyo University of Science, 1-3 Kagurazaka, Shinjuku, Tokyo 1628601, Japan \\ ${ }^{3}$ Institute of Advanced Biomedical Engineering and Science, Tokyo Women's Medical University, 8-1 Kawadacho, \\ Shinjuku, Tokyo 1620054, Japan
}

Correspondence should be addressed to Kazuo Umemura; meicun2006@163.com

Received 19 February 2016; Revised 7 May 2016; Accepted 17 May 2016

Academic Editor: Dong Wang

Copyright (C) 2016 Kazuo Umemura et al. This is an open access article distributed under the Creative Commons Attribution License, which permits unrestricted use, distribution, and reproduction in any medium, provided the original work is properly cited.

Poly( $N$-isopropylacrylamide) (PNIPAAm) is one of the most popular thermoresponsive polymers. Adsorption of RecA proteins onto hybrids of PNIPAAm and single-walled carbon nanotubes (SWNTs) was observed in the presence and absence of DNA molecules. Although RecA molecules were adsorbed efficiently onto the hybrid surfaces at $37^{\circ} \mathrm{C}$, even in the absence of DNA molecules, the adsorption of RecA was inhibited at $4^{\circ} \mathrm{C}$. These results suggest that the thermoresponsive functions of PNIPAAm were effective, even on the SWNT surfaces, which supports the possibility of developing nanobiodevices using PNIPAAm-SWNT hybrids. However, although RecA is a DNA binding protein, there was no significant difference in the adsorption of RecA onto PNIPAAm-SWNT surfaces with and without DNA molecules. This study provides fundamental information for potential biological applications of PNIPAAm-SWNT hybrids.

\section{Introduction}

Poly( $N$-isopropylacrylamide) (PNIPAAm) is one of the most common thermoresponsive polymers owing to its lower critical solution temperature (LCST) of $32^{\circ} \mathrm{C}$. It is well known that PNIPAAm molecules are hydrophobic at temperatures above $32^{\circ} \mathrm{C}$ and hydrophilic at temperatures below $32^{\circ} \mathrm{C}[1-$ 4]. Moreover, the LCST does not depend on the polymer molecular weight, as long as $M_{w}$ is greater than $50,000 \mathrm{Da}$ [5]. Because of these unique properties, PNIPAAm and related polymers have been intensively studied $[6,7]$. These polymers have been used for various biomedical applications, such as the preparation of cell sheets $[3,4]$. In addition, the fabrication of PNIPAAm polymer brushes on reduced graphene oxide and hydrogel-forming polymer films have been reported, respectively $[8,9]$.

Carbon nanotubes (CNTs) are also promising nanomaterials for various industrial and biological applications [1014]. For biological applications, CNT surfaces are typically wrapped with organic molecules or biomolecules such as DNA $[15,16]$. This wrapping procedure has two purposes. First, although CNTs are insoluble in aqueous solutions, they can become soluble after being wrapped with hydrophilic organic molecules or biomolecules. Second, CNT surfaces can be functionalized by the aforementioned wrapping. For example, if CNT surfaces are wrapped with single-stranded DNA molecules, the resulting DNA-CNT hybrids can be used for hybridization with complementary DNA molecules.

The preparation of CNT surfaces with PNIPAAm or related molecules has been intensively studied by many authors. In most of the previously reported cases, PNIPAAm molecules were covalently attached to CNT surfaces [17-20]. However, in this procedure, the honeycomb carbon structures of the CNTs become disordered as a result of covalent bonding. Moreover, the unique optical and electronic properties of single-walled carbon nanotubes (SWNTs) are lost owing to this disorder. Wrapping molecules via physisorption is another approach for exploiting the 
unique optical and electronic properties of SWNTs. However, to the best of our knowledge, there is only one report on the preparation of PNIPAAm-SWNT hybrids by physisorption [21].

In the present study, we demonstrate the reactions of RecA proteins and DNA with PNIPAAm-SWNT hybrids at two different temperatures $\left(37^{\circ} \mathrm{C}\right.$ and $\left.4^{\circ} \mathrm{C}\right)$. RecA is one of the most important proteins associated with DNA recombination. RecA proteins bind to single-stranded DNA and form a helical filament structure [22]. Adsorption of RecA proteins onto single-stranded DNA molecules on SWNT surfaces was reported by Oura et al. [23]. PNIPAAm-SWNT hybrids have swelled rod-like structures; this suggests random physisorption of PNIPAAm onto the SWNT surfaces. Therefore, RecA proteins could randomly absorb onto PNIPAAm-SWNT hybrids. Accordingly, this study aims to provide fundamental information regarding the potential biological applications of PNIPAAm-SWNT hybrids.

\section{Materials and Methods}

SWNT powder (Super Purified HiPco SWNTs) was purchased from Unidym, Inc. (Menlo Park, CA, USA). PNIPAAm was obtained by telomerization using $N$-isopropylacrylamide, 2-mercaptoethanol (MeEtOH), and 2,2' -azobis(isobutyronitrile) (AIBN) [24]. The molecular weight of PNIPAAm-OH was characterized using $1 \mathrm{H}$ NMR (INOVA 400; Varian, Palo Alto, CA, USA) and gel permeation chromatography (GPC) (HLC-8320GPC; Tosoh, Tokyo, Japan). The GPC system was equipped with three sequentially connected columns (TSKgel Super Aw2500, TSKgel Super AW3000, and TSKgel Super AW4000; Tosoh) and calibrated using polystyrenes with various defined molecular weights (Sigma-Aldrich, St. Louis, MO, USA). The GPC experiments were carried out at $40^{\circ} \mathrm{C}$ using DMF containing $50 \mathrm{mM} \mathrm{LiCl}$ as the eluent (flow rate, $0.6 \mathrm{~mL} / \mathrm{min}$ ). Thus, the molecular weight of synthesized PNIPAAm-OH was confirmed to be 6,000 Da. DNA (thymine 30 mers, T30) and RecA proteins $(1.0 \mathrm{mg} / \mathrm{mL})$ were purchased from Life Technologies Inc. (Tokyo, Japan) and Bio Academia (Osaka, Japan), respectively.

Wang and Chen reported that PNIPAAm molecules can adsorb onto SWNT surfaces [21]. To prepare hybrids of PNIPAAm and SWNT, we used the sonication method. SWNT powder (1 mg) was added to $4 \mathrm{~mL}$ of PNIPAAm solution $(1 \mathrm{mg} / \mathrm{mL})$. The mixture was sonicated using an ultrasonic homogenizer (VCX 130, Sonics \& Materials Inc., Newtown, CT, USA) at $5 \mathrm{~W}$ for $90 \mathrm{~min}$ in ice water. To remove excess PNIPAAm molecules, the samples were centrifuged $(20130 \times \mathrm{g}, 10 \mathrm{~min})$ after adding $20 \mu \mathrm{L}$ of $1 \mathrm{M}$ tris(hydroxymethyl)aminomethane-HCl (Tris- $\mathrm{HCl}$ ) buffer solution to $180 \mu \mathrm{L}$ of the mixture. Then, the supernatant was replaced with pure water. After repeating this treatment 10 times, the precipitates with pure water were sonicated in an ultrasonic bath (LEO-80, Steady Ultrasonic Sdn. Bhd., Selangor, Malaysia) for $10 \mathrm{~min}$ in ice water to resuspend the mixture. These resuspended mixtures were used as the PNIPAAm-SWNT suspension (stock suspension A). For DNA adsorption, $500 \mu \mathrm{L}$ of DNA solution $(1 \mathrm{mg} / \mathrm{mL})$ and
$500 \mu \mathrm{L}$ of the stock suspension A were mixed and then stored at $4^{\circ} \mathrm{C}$ (stock suspension $\mathrm{B}$ ).

For characterization, eight kinds of mixtures were prepared as follows: $8 \mu \mathrm{L}$ of stock suspension A and $13 \mu \mathrm{L}$ of water were mixed. The mixture was incubated for $60 \mathrm{~min}$ at $4^{\circ} \mathrm{C}$ (sample \#1) or $37^{\circ} \mathrm{C}$ (sample \#5). For DNA samples, $16 \mu \mathrm{L}$ of stock suspension $\mathrm{B}$ and $5 \mu \mathrm{L}$ of water were mixed. The mixture was incubated for $60 \mathrm{~min}$ at $4^{\circ} \mathrm{C}$ (sample \#2) or $37^{\circ} \mathrm{C}$ (sample \#6). For experiments measuring RecA absorption onto PNIPAAm-SWNT, $8 \mu \mathrm{L}$ of stock suspension A, $5 \mu \mathrm{L}$ of RecA with adenosine $5^{\prime}$ - $[\gamma$-thio $]$ triphosphate tetralithium salt (ATP $\gamma \mathrm{S})$, and $8 \mu \mathrm{L}$ of water were mixed. The mixture was incubated for $60 \mathrm{~min}$ at $4^{\circ} \mathrm{C}$ (sample \#3) or $37^{\circ} \mathrm{C}$ (sample \#7). Finally, for experiments measuring RecA adsorption onto PNIPAAm-SWNT with DNA, $16 \mu \mathrm{L}$ of stock suspension B and $5 \mu \mathrm{L}$ of RecA solution with ATP $\gamma \mathrm{S}$ were mixed. The mixture was then incubated for $60 \mathrm{~min}$ at $4^{\circ} \mathrm{C}$ (sample \#4) or $37^{\circ} \mathrm{C}$ (sample \#8). In samples \#3, \#4, \#7, and \#8, the final concentrations of RecA and ATP $\gamma \mathrm{S}$ were $160 \mu \mathrm{g} / \mathrm{mL}$ and $2 \mathrm{mM}$, respectively. The contents of each sample are summarized in Table 1.

For atomic force microscopy (AFM) observations, $20 \mu \mathrm{L}$ of each mixture was dropped on a mica surface pretreated with 3-aminopropyltriethoxysilane (AP-mica), incubated at room temperature for $10 \mathrm{~min}$, and rinsed with pure water. The samples were dried overnight before AFM observation. The AFM observations were performed using AC-AFM mode (MFP-3D microscope; Asylum Research, Santa Barbara, CA, USA) with a silicon cantilever (NANOSENSORS PPPNCSTR-W; NanoWorld AG, Neuchâtel, Switzerland) in air. Cross-sectional analysis was carried out (100 cross-sections, five positions for 20 hybrids) to estimate the heights of the hybrids.

For agarose gel electrophoresis, $2 \mu \mathrm{L}$ of glycerol was added to $10 \mu \mathrm{L}$ of the sample mixture. The electrophoresis was carried out at $50 \mathrm{~V}$ for $60 \mathrm{~min}$ in Tris-Acetate buffer solution with ethylenediaminetetraacetic acid (TAE) using a $0.5 \%$ agarose gel. All characterizations were carried out at room temperature.

\section{Results and Discussion}

Figure 1 shows a schematic representation of the reactions examined in our experiments. DNA molecules and/or RecA proteins reacted with the PNIPAAm-SWNT hybrids at $4^{\circ} \mathrm{C}$ and $37^{\circ} \mathrm{C}$. For experiments carried out on the reactions of both DNA and RecA, the mixture of DNA and PNIPAAmSWNT was preincubated before adding the RecA proteins. AFM images of the PNIPAAm-SWNT hybrids prepared at $4^{\circ} \mathrm{C}$ and $37^{\circ} \mathrm{C}$ in the presence of DNA molecules (samples \#2 and \#6, resp.) are shown in Figure SP1 (see Supplementary Material available online at http://dx.doi.org/ 10.1155/2016/3539609); AFM images of the hybrids prepared in the absence of DNA (samples \#1 and \#5, resp.) are shown in Figure SP2. No apparent differences in the morphologies were observed among these four samples. In comparison with hybrids of DNA and SWNTs [23, 25, 26], the variance of height values that were obtained from the cross-sectional analysis of the AFM images was quite large. The average height values were $4.5 \pm 3.7,6.8 \pm 14.0,5.9 \pm 4.4$, and $5.0 \pm 4.6 \mathrm{~nm}$ 
TABLE 1: Contents of each sample.

\begin{tabular}{|c|c|c|c|c|c|c|}
\hline Sample number & $\begin{array}{l}\text { PNIPAAm- } \\
\text { SWNT } \\
\text { suspension } \\
(\mu \mathrm{L})\end{array}$ & $\begin{array}{c}\text { DNA } \\
\text { solution }(\mu \mathrm{L})\end{array}$ & $\begin{array}{c}\text { RecA } \\
\text { solution with } \\
\text { ATP } \gamma \mathrm{S}(\mu \mathrm{L})\end{array}$ & Water $(\mu \mathrm{L})$ & $\begin{array}{c}\text { Incubation } \\
\text { temperature } \\
\left({ }^{\circ} \mathrm{C}\right)\end{array}$ & $\begin{array}{c}\text { Average } \\
\text { height values } \\
(\mathrm{nm})\end{array}$ \\
\hline$\# 1$ & 8 & 0 & 0 & 13 & 4 & $4.5 \pm 3.7$ \\
\hline \#2 & 8 & 8 & 0 & 5 & 4 & $6.8 \pm 14.0$ \\
\hline \#3 & 8 & 0 & 5 & 8 & 4 & $7.4 \pm 6.0$ \\
\hline \#4 & 8 & 8 & 5 & 0 & 4 & $7.0 \pm 5.4$ \\
\hline$\# 5$ & 8 & 0 & 0 & 13 & 37 & $5.9 \pm 4.4$ \\
\hline \#6 & 8 & 8 & 0 & 5 & 37 & $5.0 \pm 4.6$ \\
\hline$\# 7$ & 8 & 0 & 5 & 8 & 37 & N.A. \\
\hline$\# 8$ & 8 & 8 & 5 & 0 & 37 & $7.8 \pm 5.7$ \\
\hline
\end{tabular}

In each sample, the final concentration of PNIPAAm-SWNT was $380 \mu \mathrm{g} / \mathrm{mL}$. In samples \#2, \#4, \#6, and \#8, the final concentration of DNA was $380 \mu \mathrm{g} / \mathrm{mL}$. In samples \#3, \#4, \#7, and \#8, the final concentrations of RecA and ATP $\gamma$ S were $160 \mu \mathrm{g} / \mathrm{mL}$ and $2 \mathrm{mM}$, respectively.

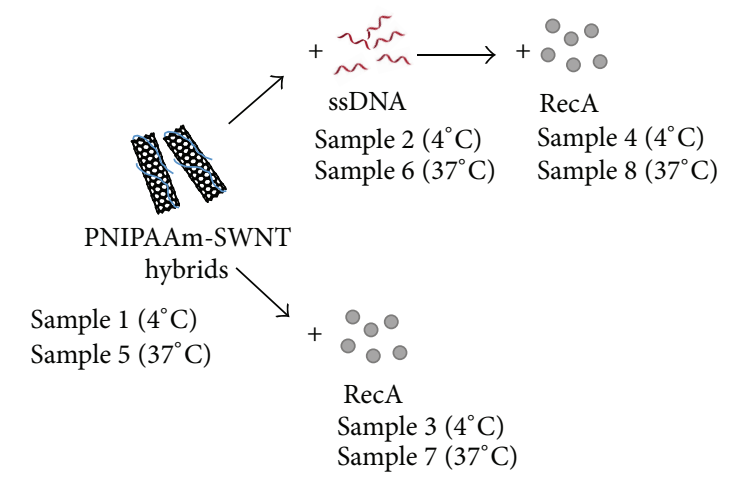

FIGURE 1: Schematic representation of the reactions studied.

for PNIPAAm-SWNT without DNA at $4^{\circ} \mathrm{C}$ (sample \#1), PNIPAAm-SWNT with DNA at $4^{\circ} \mathrm{C}$ (sample \#2), PNIPAAmSWNT without DNA at $37^{\circ} \mathrm{C}$ (sample \#5), and PNIPAAmSWNT with DNA at $37^{\circ} \mathrm{C}$ (sample \#6), respectively. Although the average height of each sample was slightly different, it is not obvious whether DNA was attached to PNIPAAm-SWNT because the standard deviation of each sample, especially that of sample \#2, was large. This irregularity of the standard deviations may be caused by non-Gaussian distributions.

The RecA proteins reacted with PNIPAAm-SWNT with and without DNA molecules at $4^{\circ} \mathrm{C}$ and $37^{\circ} \mathrm{C}$. Because RecA is one of the major DNA binding proteins, we were interested in the binding of RecA proteins to PNIPAAm-SWNT hybrids. At $4^{\circ} \mathrm{C}$, no significant changes were observed, even after adding RecA proteins. Figure 2(a) shows an AFM image of the PNIPAAm-SWNT hybrids with RecA (sample \#3). In this case, RecA proteins directly reacted with PNIPAAmSWNT hybrids without DNA. On the other hand, as shown in Figure 2(b), when DNA was added to PNIPAAm-SWNT hybrids first, the RecA proteins reacted with the mixture of DNA and PNIPAAm-SWNT hybrids (sample \#4). There were no significant changes in the morphologies of these samples when compared with the results shown in Figures SP1 and
SP2. The average heights were $7.4 \pm 6.0$ and $7.0 \pm 5.4 \mathrm{~nm}$ for PNIPAAm-SWNT with RecA (sample \#3) and PNIPAAmSWNT with DNA and RecA (sample \#4), respectively. These values are obviously larger than that for PNIPAAm-SWNT without RecA and DNA (sample \#1), which suggests that RecA proteins are bound to PNIPAAm-SWNT surfaces both with and without DNA molecules.

Similar experiments were carried out at $37^{\circ} \mathrm{C}$. In this case, the morphologies of the PNIPAAm-SWNT hybrids were drastically changed compared with those at $4^{\circ} \mathrm{C}$. Many large hybrids were observed in the images of both sample \#7 (Figure 2(c)) and sample \#8 (Figure 2(d)). In particular, many aggregated hybrids were found in PNIPAAm-SWNT with RecA (Figure 2(c); sample \#7), and a cross-sectional analysis was therefore not possible in the case. An additional AFM image is shown in Figure 2(c) instead of a histogram. The average height of PNIPAAm-SWNT with DNA and RecA (sample \#8) was $7.8 \pm 5.7 \mathrm{~nm}$, which is a higher value than those for PNIPAAm-SWNT hybrids with and without DNA (samples \#5 and \#6, resp.).

From the above results, we can conclude that RecA proteins tend to bind with the PNIPAAm-SWNT hybrids at $37^{\circ} \mathrm{C}$, even in the absence of DNA molecules. For PNIPAAmSWNT with RecA in the absence of DNA, more RecA proteins were attached to PNIPAAm-SWNT at $37^{\circ} \mathrm{C}$ (sample \#7) than at $4^{\circ} \mathrm{C}$ (sample \#3). However, in the presence of DNA molecules, the change of the average height between $4^{\circ} \mathrm{C}$ (sample \#4) and $37^{\circ} \mathrm{C}$ (sample \#8) was not significant. Thus, the thermoresponsive properties of PNIPAAm were useful for regulating RecA protein attachment to the SWNT surfaces in the absence of DNA molecules. On the other hand, the aggregation of the hybrids in the absence of DNA molecules is not well understood. Further experiments are necessary to clarify the mechanisms underlying the adhesion of RecA proteins onto the PNIPAAm-SWNT surface without DNA and the aggregation of the hybrids.

Finally, the samples were analyzed using agarose gel electrophoresis (Figure 3). The location of each band of SWNTs can be observed without staining. Lanes 1 and 5 show 

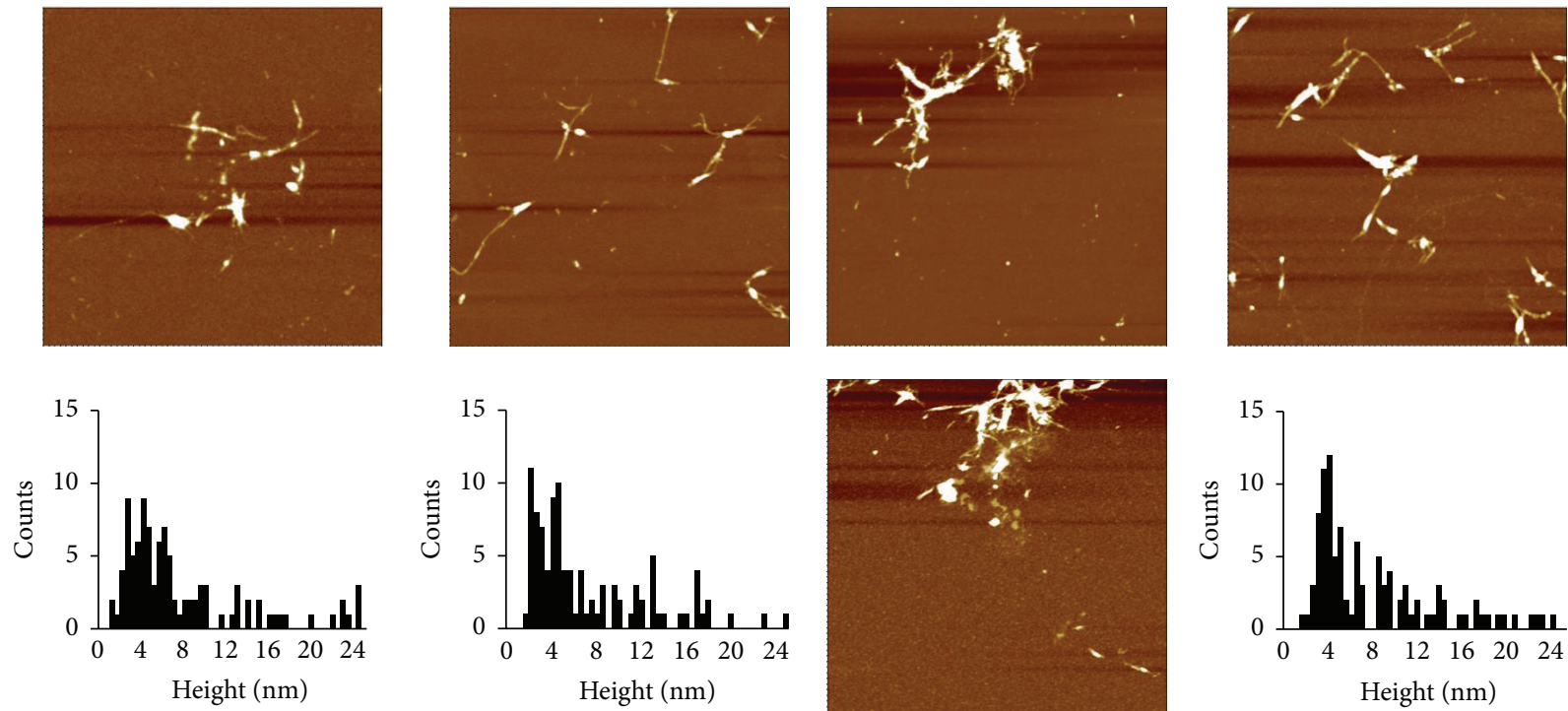

(a)

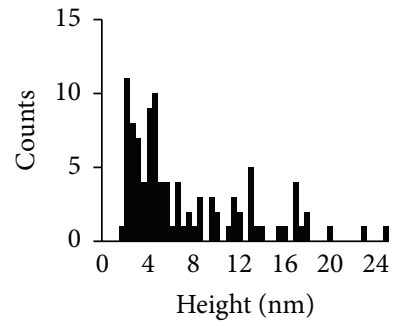

(b)

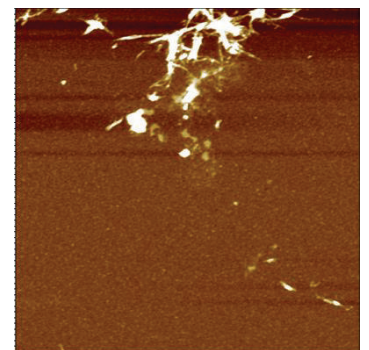

(c)

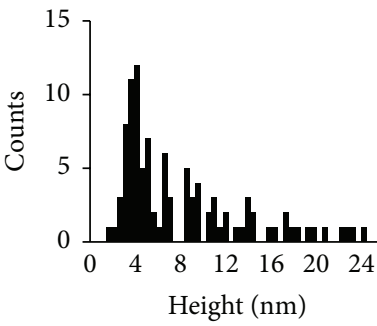

(d)

FIgURE 2: AFM images and height distributions of PNIPAAm-SWNT hybrids with DNA and/or RecA. (a) PNIPAAm-SWNT with RecA incubated at $4^{\circ} \mathrm{C}$ (sample \#3). (b) PNIPAAm-SWNT with DNA and RecA incubated at $4^{\circ} \mathrm{C}$ (sample \#4). (c) PNIPAAm-SWNT with RecA incubated at $37^{\circ} \mathrm{C}$ (sample \#7). (d) PNIPAAm-SWNT with DNA and RecA incubated at $37^{\circ} \mathrm{C}$ (sample \#8). Scan size: $3.0 \mu \mathrm{m} \times 3.0 \mu \mathrm{m}$.

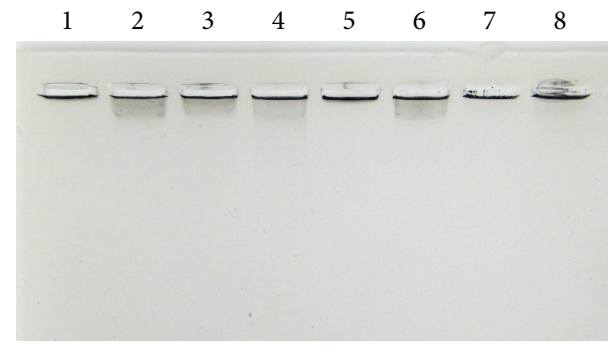

FIGURE 3: Agarose gel electrophoresis of PNIPAAm-SWNT hybrids. Lanes 1-4: samples incubated at $4^{\circ} \mathrm{C}$. Lanes 5-8: samples incubated at $37^{\circ} \mathrm{C}$. Lanes 1 and 5: PNIPAAm-SWNT. Lanes 2 and 6: PNIPAAmSWNT with DNA. Lanes 3 and 7: PNIPAAm-SWNT with RecA. Lanes 4 and 8: PNIPAAm-SWNT with DNA and RecA.

the PNIPAAm-SWNT hybrids prepared at $4^{\circ} \mathrm{C}$ (sample \#1) and $37^{\circ} \mathrm{C}$ (sample \#5), respectively. In these cases, the SWNTs remained in the loading well, even after $1 \mathrm{~h}$ electrophoresis. Lanes 2 and 6 show the mixtures of DNA and PNIPAAmSWNT at $4^{\circ} \mathrm{C}$ (sample \#2) and $37^{\circ} \mathrm{C}$ (sample \#6), respectively. In these cases, some of the SWNTs migrated; thus, the results suggest that DNA adsorbed onto the PNIPAAmSWNT surfaces, although this was not obvious in the crosssectional analysis of the AFM images. When RecA proteins were added at $4^{\circ} \mathrm{C}$ (Lanes 3 and 4 ; samples \#3 and \#4, resp.), the SWNT bands were similar to that in Lane 2 (sample \#2). In our experiments, RecA proteins are negatively charged $[27,28]$. Therefore, this result suggests that a small amount of RecA proteins adsorbed onto the PNIPAAm-SWNT surfaces at $4^{\circ} \mathrm{C}$. On the other hand, with the addition of RecA proteins at $37^{\circ} \mathrm{C}$, the SWNTs remained in the loading wells in Lanes 7 (sample \#7) and 8 (sample \#8) and in Lanes 1 (sample \#1) and 5 (sample \#5). This result might suggest an increase in the molecular weight of the hybrids due to the binding of large amounts of RecA proteins.

\section{Conclusion}

In this work, we demonstrated the attachment of RecA proteins onto PNIPAAm-SWNT hybrids. The amount of adsorbed RecA proteins was found to be regulated by temperature in the absence of DNA molecules. To regulate the reactions of RecA and DNA molecules on PNIPAAmSWNT surfaces, further improvement of sample conditions is necessary.

\section{Competing Interests}

The authors declare that they have no competing interests.

\section{Acknowledgments}

This work was supported by a Grant-in-Aid for Scientific Research (26400436) of the Japan Society for the Promotion of Science (JSPS).

\section{References}

[1] M. Heskins and J. E. Guillet, "Solution properties of poly(Nisopropylacrylamide)," Journal of Macromolecular Science: Part A-Chemistry, vol. 2, no. 8, pp. 1441-1455, 1968.

[2] H. Kanazawa and T. Okano, "Temperature-responsive chromatography for the separation of biomolecules," Journal of Chromatography A, vol. 1218, no. 49, pp. 8738-8747, 2011.

[3] T. Okano, N. Yamada, M. Okuhara, H. Sakai, and Y. Sakurai, "Mechanism of cell detachment from temperature-modulated, hydrophilic-hydrophobic polymer surfaces," Biomaterials, vol. 16, no. 4, pp. 297-303, 1995. 
[4] Z. Tang, Y. Akiyama, and T. Okano, "Temperature-responsive polymer modified surface for cell sheet engineering," Polymers, vol. 4, no. 3, pp. 1478-1498, 2012.

[5] S. Furyk, Y. Zhang, D. Ortiz-Acosta, P. S. Cremer, and D. E. Bergbreiter, "Effects of end group polarity and molecular weight on the lower critical solution temperature of poly $(\mathrm{N}$ isopropylacrylamide)," Journal of Polymer Science, Part A: Polymer Chemistry, vol. 44, no. 4, pp. 1492-1501, 2006.

[6] H. W. Chen, J. F. Li, Y. W. Ding, G. Z. Zhang, Q. J. Zhang, and C. Wu, "Folding and unfolding of individual PNIPAM-g-PEO copolymer chains in dilute aqueous solutions," Macromolecules, vol. 38, no. 10, pp. 4403-4408, 2005.

[7] K. Otake, H. Inomata, M. Konno, and S. Saito, “Thermal analysis of the volume phase transition with $N$-isopropylacrylamide gels," Macromolecules, vol. 23, no. 1, pp. 283-289, 1990.

[8] Y. Yang, X. Song, L. Yuan et al., "Synthesis of PNIPAM polymer brushes on reduced graphene oxide based on click chemistry and RAFT polymerization," Journal of Polymer Science, Part A: Polymer Chemistry, vol. 50, no. 2, pp. 329-337, 2012.

[9] L. Wang and Y. Ding, "Creating micro-structured hydrogelforming polymer films by photopolymerization in an evaporating solvent: compositional and morphological evolutions," European Polymer Journal, vol. 66, pp. 99-107, 2015.

[10] N. Nakashima, S. Okuzono, H. Murakami, T. Nakai, and K. Yoshikawa, "DNA dissolves single-walled carbon nanotubes in water," Chemistry Letters, vol. 32, no. 5, pp. 456-457, 2003.

[11] M. Zheng, A. Jagota, E. D. Semke et al., "DNA-assisted dispersion and separation of carbon nanotubes," Nature Materials, vol. 2, no. 5, pp. 338-342, 2003.

[12] V. C. Moore, M. S. Strano, E. H. Haroz et al., "Individually suspended single-walled carbon nanotubes in various surfactants," Nano Letters, vol. 3, no. 10, pp. 1379-1382, 2003.

[13] V. Zorbas, A. Ortiz-Acevedo, A. B. Dalton et al., "Preparation and characterization of individual peptide-wrapped singlewalled carbon nanotubes," Journal of the American Chemical Society, vol. 126, no. 23, pp. 7222-7227, 2004.

[14] K. Matsuura, T. Saito, T. Okazaki, S. Ohshima, M. Yumura, and S. Iijima, "Selectivity of water-soluble proteins in singlewalled carbon nanotube dispersions," Chemical Physics Letters, vol. 429, no. 4-6, pp. 497-502, 2006.

[15] K. Umemura, "Hybrids of nucleic acids and carbon nanotubes for nanobiotechnology," Nanomaterials, vol. 5, no. 1, pp. 321$350,2015$.

[16] D. Tasis, N. Tagmatarchis, A. Bianco, and M. Prato, "Chemistry of carbon nanotubes," Chemical Reviews, vol. 106, no. 3, pp. 1105-1136, 2006.

[17] A. Tiwari, Y. Sharma, S. Hattori et al., "Influence of $\operatorname{poly}(n-$ isopropylacrylamide)-CNT-polyaniline three-dimensional electrospun microfabric scaffolds on cell growth and viability," Biopolymers, vol. 99, no. 5, pp. 334-341, 2013.

[18] G. Y. Xu, W.-T. Wu, Y. S. Wang et al., "Synthesis and characterization of water-soluble multiwalled carbon nanotubes grafted by a thermoresponsive polymer," Nanotechnology, vol. 17, no. 10, pp. 2458-2465, 2006.

[19] C.-Y. Hong, Y.-Z. You, and C.-Y. Pan, "Synthesis of watersoluble multiwalled carbon nanotubes with grafted temperature-responsive shells by surface RAFT polymerization," Chemistry of Materials, vol. 17, no. 9, pp. 2247-2254, 2005.

[20] Y.-L. Liu and W.-H. Chen, "Modification of multiwall carbon nanotubes with initiators and macroinitiators of atom transfer radical polymerization," Macromolecules, vol. 40, no. 25, pp. 8881-8886, 2007.
[21] D. Wang and L. Chen, "Temperature and pH-responsive singlewalled carbon nanotube dispersions," Nano Letters, vol. 7, no. 6, pp. 1480-1484, 2007.

[22] Z. C. Chen, H. J. Yang, and N. P. Pavletich, "Mechanism of homologous recombination from the RecA-ssDNA/dsDNA structures," Nature, vol. 453, no. 7194, pp. 489-494, 2008.

[23] S. Oura, M. Ito, D. Nii, Y. Homma, and K. Umemura, "Biomolecular recognition ability of RecA proteins for DNA on singlewalled carbon nanotubes," Colloids and Surfaces B: Biointerfaces, vol. 126, pp. 496-501, 2015.

[24] Y. G. Takei, T. Aoki, K. Sanui, N. Ogata, T. Okano, and Y. Sakurai, "Temperature-responsive bioconjugates. 2. Molecular design for temperature-modulated bioseparations," Bioconjugate Chemistry, vol. 4, no. 5, pp. 341-346, 1993.

[25] D. Nii, T. Hayashida, and K. Umemura, "Controlling the adsorption and desorption of double-stranded DNA on functionalized carbon nanotube surface," Colloids and Surfaces B: Biointerfaces, vol. 106, pp. 234-239, 2013.

[26] D. Nii, T. Hayashida, Y. Yamaguchi, S. Ikawa, T. Shibata, and K. Umemura, "Selective binding of single-stranded DNA-binding proteins onto DNA molecules adsorbed on single-walled carbon nanotubes," Colloids and Surfaces B: Biointerfaces, vol. 121, pp. 325-330, 2014.

[27] L. J. Gudas and A. B. Pardee, "DNA synthesis inhibition and the induction of protein X in Escherichia coli," Journal of Molecular Biology, vol. 101, no. 4, pp. 459-477, 1976.

[28] A. Pierre and C. Paoletti, "Purification and characterization of recA protein from Salmonella typhimurium," The Journal of Biological Chemistry, vol. 258, no. 5, pp. 2870-2874, 1983. 

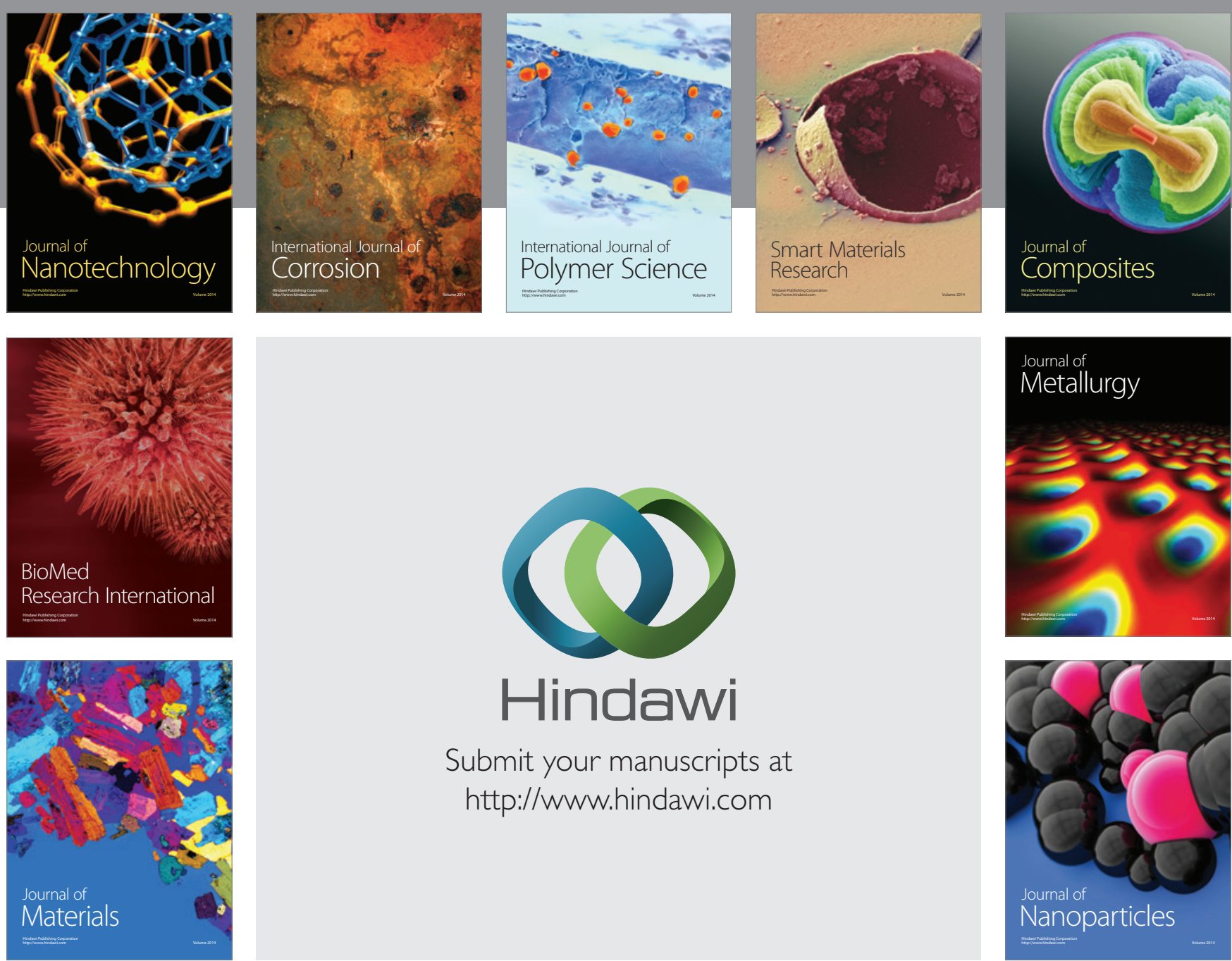

\section{Hindawi}

Submit your manuscripts at

http://www.hindawi.com

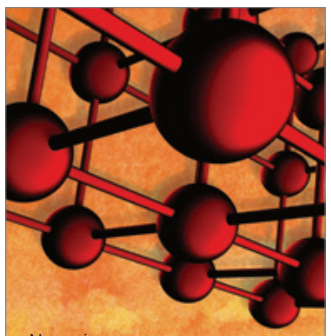

Materials Science and Engineering
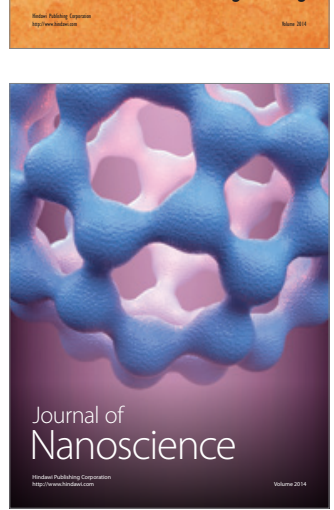
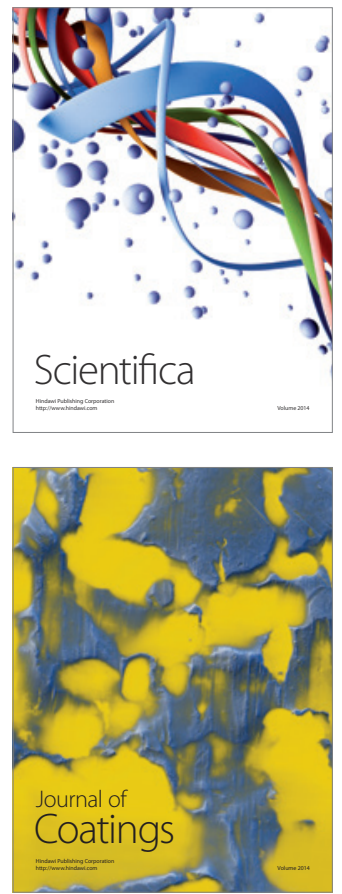
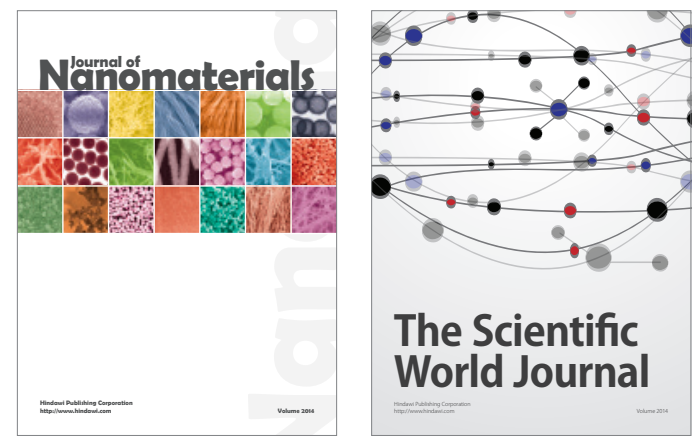

The Scientific World Journal
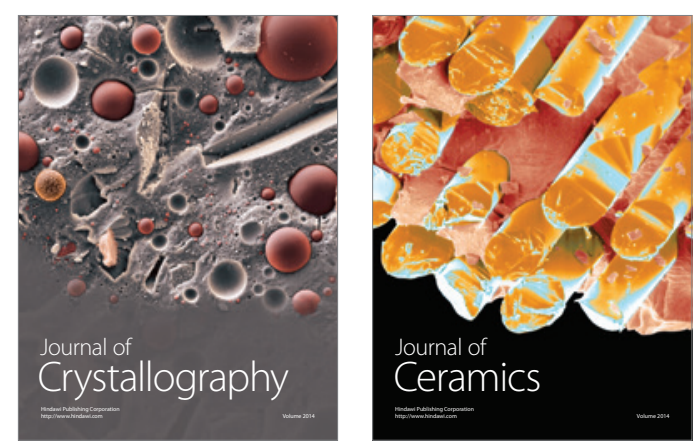
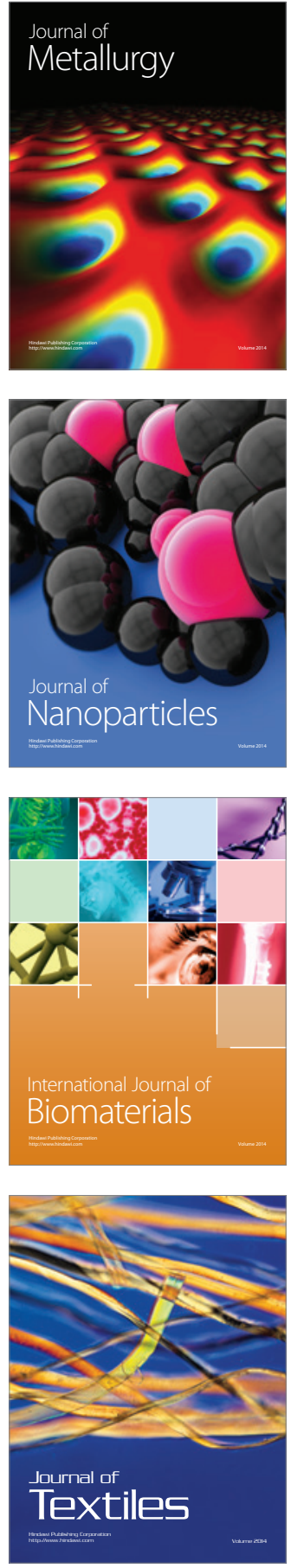